\title{
(5)

\section{Paa den tid da blaabærene holdt paa at modnes}

TIDLIGERE I TIDSSKRIFTET

JULIE DIDRIKSEN

Tidsskriftet

Dette er historien om legen som ble tilkalt til en fjellgård omtrent 50 kilometer inn i dalstrøkene på Vestlandet. Gårdskona hadde fått en svært vond byll på magen, og selv om inngrepet burde vente til dagen etter, «var der ikke raad for annet» enn å tømme den der og da i det dunkle lyset fra et lite talglys. Dette er også historien om menneskene han møtte på vei ned igjen, som lurte på hvordan det gikk med henne, og om modne blåbær. Ikke minst er det også historien om turen til sykehuset som pasienten ikke tok, til tross for legens anbefalinger (Tidsskr Nor Lægeforen 1926; 46: 263).

\section{Hvad et menneske kan taale.}

Av R. M. Bergh, Jevnaker

Det er for over 23 aar siden, at jeg utpaa sommeren paa den tid «da blaabærene holdt paa at modnes», blev budsendt til en kone omtr. 50 kilometer borte i en fjeldgaard i mit distrikt paa Vestlandet. - Konen skulde ha «en byld paa maven». Til hendes hjem kom jeg sent om kvelden, det var mørkt i det lille stenmurte rum hvor hun laa. Litt opad for høire ingven buket der sig frem i en tokronestor utstrækning en rødlig fluktuerende tumor opstaat paa kort tid. - Der var ingen broksymptomer; hun hadde hat smerter i ileocoekalregionen i $1 \frac{1}{2}$ aars tid. Konen hadde store smerter - der forlangtes energisk aapning av bylden - jeg hadde mest lyst til at utsætte med indgrepet til mere lys om morgenen, - der var forhaanden ikke andet end et litet talglys; petroleumskanden var ikke blit fyldt endda paa den aarstid, og der var langt til handelsmanden.- 


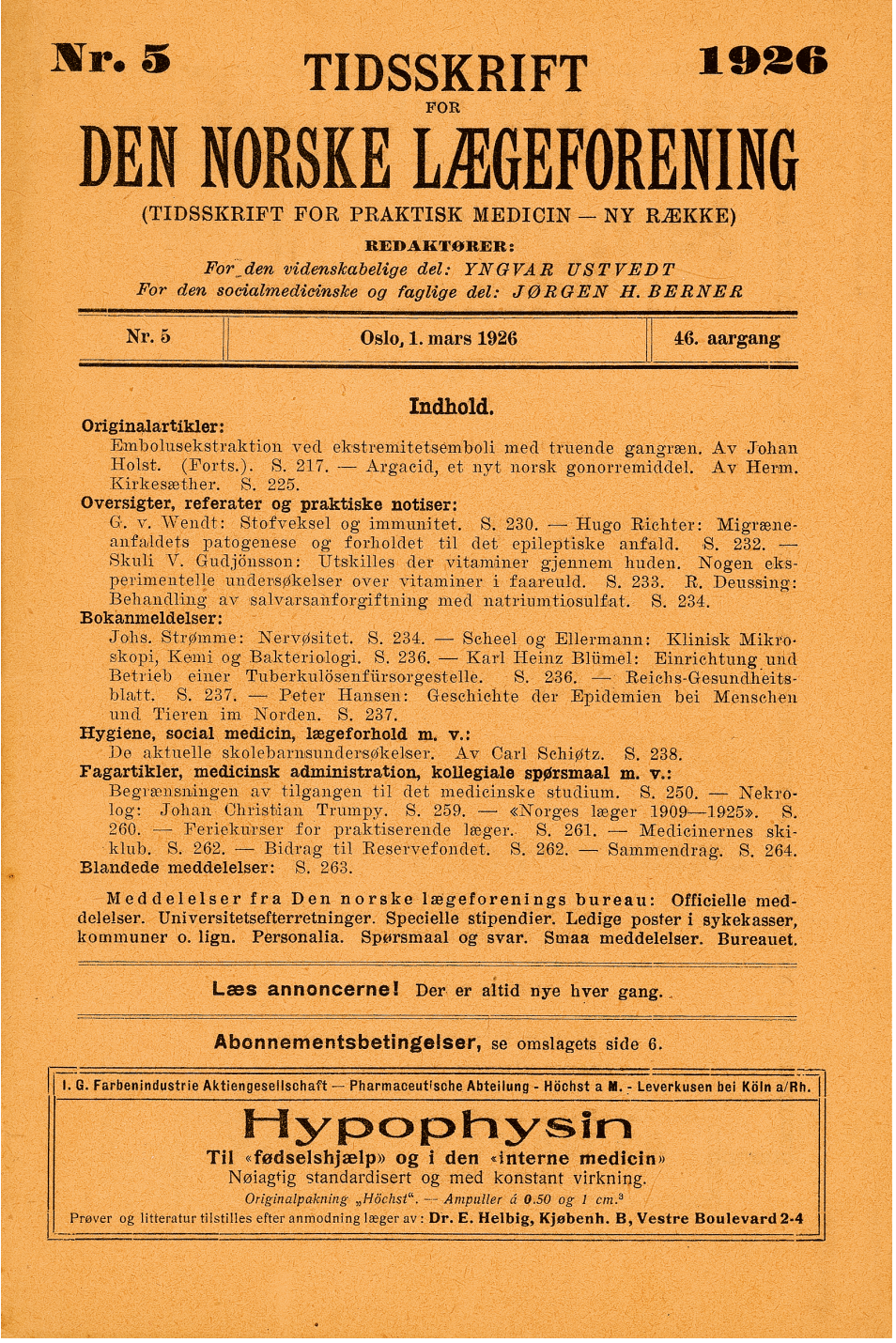

Der maatte imidlertid tages affære, der var ikke raad for andet. Jeg gjorde da en forsigtig incision; ut stod en stinkende pusstraale av aapningen. Pludselig stopper straalen og en hvitlig tjavse har sat sig i aapningen. Med en fin Listers drænrørstang nappet jeg i den, og ut kom et omtr. $3 \mathrm{~cm}$. langt blindsækformet stykke tarm (appendix?) med gangrænøs rand. Da begyndte pus igjen at strømme ut i masser. Da pusset var rendt ut, rensedes med steril gaze og saarbunden tamponertes. - Dagens gjerning var endt.

Da jeg om morgenen tilsaa konen, befandt hun sig vel, og da tamponen var ombyttet, sa jeg hende at hun maatte til sykehus.

Den første mil nedover dalen hadde jeg den dag travelt med at svare folk paa spørsmaal om konens befindende.

Omtr. 14 dager efter kommer konens mand til mig. Jeg trodde han vilde fortælle mig at konen nu var vel hjemme igjen fra sykehuset. Men nei - hun var ikke reist endda.

«Det doktoren hadde lagt ind var gaat ut de første dagene, og der kom ikke mere materie. Men,» sa han, «der maa være forbindelse med tarmen og de saar, som doktoren skar. Her en dag spiste hun blaabær, og de kom ut gjennem saaret.»

Manden, som hadde liten raad til sykehusbehandling og operation av konen, hadde ikke sagt ifra da jeg ordinerte dette - kredssykekassen var ikke kommet i sving før flere aar efter. I en fart fik jeg da ordnet det saa at hun med fattigvæsenets hjelp kunde opereres i sykehus.

Hun taalte den 50 kilometer lange kjøretur i en skranglekjærre og dampskibsturen efterpaa til by, hvor der saa blev foretat resektion av et stykke gangrænøs tarm. Konen hadde intet mén efterpaa av tarmhistorien, men bukket under nogen aar efter av akut lungetuberkulose. 
Publisert:3. september 2018. Tidsskr Nor Legeforen. DOI:10.4045/tidsskr.18.0467 (C) Tidsskrift for Den norske legeforening 2020. Lastet ned fra tidsskriftet.no 